\title{
试析城乡供水一体化管理服务的创新路径
}

杨燕宇

平塘县水务局

DOI:10.32629/hwr.v3i4.2027

[摘 要] 城乡供水一体化管理是对现有城乡供水体制改革的深化落实和完善,其一方面实现了城乡供水价格的调整, 另一方 面也保证了城乡居民饮用水质量以及供水服务质量,并为城乡经济的发展奠定了坚实基础。

[关键词]城乡供水一体化; 管理; 创新路径

城乡供水一体化管理的实施在实现水资源的统一管理、 优化城乡水资源方面起到了非常关键的作用。提高城乡供水 一体化管理服务是提高和完善城乡经济发展的必要途径, 且 对城乡供水一体化服务不断进行创新具有重要意义。

\section{1 我国实行城乡供水一体化的背景}

1.1 城乡供水一体化的必要性

为实现我国小康社会的建设目标, 就需要有效解决城乡 一体化发展中存在的矛盾和问题, 推动城乡经济的共同发展 与进步, 而城乡供水一体化是目前城乡经济发展中面临的主 要问题之一, 水资源一直都是人们赖以生存的重要资源, 供 水的合理性与及时性对于保证人们生活, 提高生产效率和水 平有着非常重要的作用, 所以对城乡供水一体化进行创新, 实现水资源的合理保护与利用是城乡一体化发展中较为重 要的内容。

\section{2 城乡供水一体化的地方背景}

以某城市为例, 其在近几年城乡经济发展中坚持了农村 供水城市化、城乡供水一体化的基本原则和目标, 同时加大 了财政方面的投资力度, 推进城乡居民饮水安全工程的建 设。截止到目前, 该城市城乡一体化供水人口较起初提升了 0.5 倍左右, 供水面积可达到 16 万立方米左右, 水质综合率 可达到百分百。同时, 该城市为了更好的适应社会发展需求, 还在不断加大相关资金的投放力度, 并制定了一系列改善措 施, 以推动城乡供水一体化的进一步发展。如加大财政投资 力度, 开展水源扩容工程、优化传统的工艺净化水厂, 以提高 水质水量, 且取得了较好的成效, 更好的满足了城乡居民的 用水安全。

\section{2 城乡供水一体化中存在的问题}

结合近几年城乡供水一体化情况的分析可以看出, 城乡 供水一体化仍存在着一定的问题和弊端, 如供水主要集中在 城市和城镇区域内, 农村的供水水质较差, 供水量也无法满 足人们日常生活生产的需求。尤其是对于一些偏远地区, 水 资源短缺更为严重, 再加上运营机制不完善以及供水工程的 资金投放力度较高等, 使得很多基础设施和工作无法得到有 效落实与完善, 进而影响了供水的整体质量和效果。而导致 这些问题的主要原因为:

2.1 农村地区供水体制不健全
在对我国城乡供水一体化现状进行调查研究中发现, 城 镇和城市的供水情况以及水质要求均能够达到国家规定的 标准要求范围, 满足人们的日常生活和工作。但是农村地区, 包括城市下属的农村区域内, 却存在着严重的水资源不足, 水质质量不达标的情况, 这使得农民很难引用到安全放心的 水源, 不仅威胁了农村人们的健康, 也阻碍了农村区域经济 的发展。另外, 很多农村区域在管理上仍在采用二元体制制 度, 这严重阻碍了城乡供水一体化的发展水平和效率。二元 体制管理制度的供水模式为: 乡镇府作为供水运营的主要管 理人员, 通过一系列相关政策的落实, 来实现乡镇内部水厂 的有效控制, 进而为人们提供生活生产所需水源。且乡政府 部门会定期进行水费的收取, 完成整个供水服务流程。这种 管理模式相对较为简单, 基本是由乡政府全权处理, 但是在 国家政策的落实上却存在一定差异, 且用水价格相对较高, 很容易影响农民的用水效率, 阻碍城乡供水一体化管理的效 果和水平。

\section{2 配套设施不完善}

城乡供水一体化的发展与完善需要专业的科学技术作 为有效支撑方能实现, 不过结合目前的情况分析可以看出, 城乡供水一体化中存在着较多不足之处, 如运营管理机制不 完善、监督管控体系不全面、技术水平较为落后等, 这使得 城乡供水一体化的落实存在较为严重的表面现象, 无法有效 解决现今城乡发展中存在的问题, 降低了城乡供水一体化的 整体效果。另外, 技术水平的落后, 导致城乡供水一体化的运 营存在安全性不高、自动化、信息化水平较低等多种问题, 在水质处理上存在诸多问题, 污染现象越发严重, 降低了农 民使用水的质量和安全。与此同时, 供水工程的供水管网的 建设质量不过关, 供水工程的实施导致水管压力过大, 水管 或无法正常供水或是 “带病”工作, 产生了不必要的水资源 浪费现象。

\section{3 政策支持效率低, 积极性不高}

城乡供水一体化在落实实施过程中, 虽然改变了农村用 水方式和生活方式, 不过其也要求农村对原有的基础设施以 及水价进行完善和调整, 很多农村区域担心这些调整和优化 会造成大量的成本消耗, 影响自身的经济效益, 所以在改善政 策落实上会存在着一定的消极心理, 进而导致政府政策落实 
效率较低, 监管工作不到位, 阻碍了城乡供水一体化的发展。

\section{3 城乡供水一体化建设管理的创新路径}

3.1 确保供水系统经营和管理建设的全面性, 完善供水 体系

随着信息技术的快速发展, 在城乡供水一体化管理中也 可以通过信息技术的应用来实现有效管理和控制。通过信息 技术管理模式的应用,一方面可以对城乡供水情况以及供水 管线的运转效率进行实时监督和管控; 另一方面也可以对城 乡供水中污水排放以及处理情况进行实时监督, 降低污染等 的发生, 保证供水质量。在经济技术能够满足供水管线与污 水收集管线的前提下, 将城乡供水一体化从城市向乡村地区 进行辐射, 最终达到城乡供水一体化的完整进程与发展。两 大管道的同时利用, 能够有效的提高整体水资源利用率。

3.2 完善城乡供水一体化的相关政策措施, 合理划分工 作责任

城乡供水一体化建设属于民生工程的一种, 与人们的日 常生活有着密切联系。在城乡供水一体化工程建设中, 由于 其涉及的内容较多, 影响范围较广, 需要的配套设施要求较 高, 所以需要政府部门制定一系列较为完善的政策措施, 并 落实到实际工作中, 如此才能更好的提升城乡供水一体化的 建设质量和水平。另外, 在相关政策制定和落实过程中, 还需 要各部门的积极有效配合, 以提高政策落实效率, 这就要求 对各部门的工作职责进行明确合理的划分, 并在固定时间内 召开相关的总结会议, 对供水一体化落实中存在的问题进行 提出和探讨, 制定合理的解决措施, 以保证城乡供水一体化 水平。

3.3 通过科学技术的应用加快供水管网的建设速度

供水管网是城乡供水一体化体系中较为重要的组成部 分, 只有保证管网建设的合理性、完善性, 才能确保水资源的 有效传输。在管网建设中, 应结合城乡居民的实际情况, 分阶 段、分层级的进行供水管网建设, 以确保农村水资源供应的 充足性, 提高用水质量。应提高供水方面的科学技术, 提高水 资源利用效率、降低所需成本。供水管网的建设除需要技术 手段支撑, 还需要多方面配合。

3. 3. 1 加大工程相关技术人员的专业培训水平, 提高自 身的专业素质水平, 强化突发事件的处理速度, 确保供水一 体化工程的建设效果。

3. 3.2 在供水管网建设中, 应设立专门的监管小组, 对管 线进行定期维修和养护, 确保使用安全。组建紧急抢修队伍, 一旦发现管网出现问题, 要立即进行修复和完善工作, 同时
应配备专业的抢修人员和抢修设备, 提高抢修工作的效率和 质量。

3. 3.3 设置供水管网水压测试点, 对管网运行情况进行 及时的掌握和了解, 如果发现异常要及时进行检修, 以免影 响水源正常供应, 降低用水质量, 造成较大的经济损失。

3.4 高效落实水质保障工作

水质不达标或者存在较多有害物质的水源对于居民的 身体健康有着严重影响, 所以开展相应的水质保障工作是尤 为重要的, 水质保障工作首先需要卫生防疫部门的有效配合, 定期对自来水进行检查, 避免内部较多杂质或病菌的混入; 其次对供水管网进行定期的清洁和处理, 降低污染的产生, 保证水质流通过程中的质量, 减少危害的产生。面对紧急抢 修工作, 部分自来水会因抢修工作被污染, 抢修工作完成后 亦需要对所使用水进行消毒。最后, 加强农村一户一表改建工 作的开展力度, 避免水资源二次污染的产生, 保证用水质量。

3.5 制定和落实惠民政策

城乡供水一体化工程本身就与人民自身的利益紧密相 连, 要想推动城乡供水一体化的发展, 则加大人民群众的参 与力度是尤为重要的。不过目前很多农村群众对于该工程的 理解处在偏差, 担心会造成较大的额外费用支出, 所以政府部 门应加大惠民政策的落实效率, 提高农村人们参与的积极性。

3. 5.1 水表井和水表等基础设施, 应由政府部门统一进行 订购和安装, 以减少农民的经济负担, 消除存在的隐患问题。

3. 5.2 保持城乡居民用水价格的统一性、一致性, 减少 心理落差的产生。

3.5.3 完善相关管理政策内容, 加大安全用水的监督管 理水平, 保证农村居民用水安全。

\section{4 结束语}

总之, 城乡供水一体化工程的建设对于实现水资源的合 理划分以及水质质量的提高有着重要作用。在现今发展中, 我们应结合实际情况,制定合理的管理策略和措施, 应用先 进技术加强管理水平, 保证城乡供水的及时性、有效性, 提高 城乡居民的用水安全。

\section{[参考文献]}

[1]刘长花,刘祥瑞,李冬梅.高唐县城乡供水一体化的主 要做法[J].山东水利,2017(05):54-55.

[2]李鹏,王凯. 临邑县城乡供水一体化建设探讨 [J]. 山东 水利,2017(08):26-27.

[3]常涛.平阴县城乡供水一体化的主要做法与成效 [J]. 山东水利,2016(11):49-50. 